\title{
Biological insight into design against crime
}

\author{
D. E. Santos-Reyes \\ Manufacturing and Systems Research Group, \\ Industrial Engineering Department, \\ Universidad Tecnologica de la Mixteca, \\ Km. 2.5 carretera Huajuapan-Acatlima, \\ Huajuapan de Leon, Oax. 69000, Mexico
}

\begin{abstract}
Over the last decade, designers have been seeking to improve the environmental performance of their products or systems as a result of rapidly increasing market pressures. Additionally, there is a growing concern on integrating crime issues into the design process. Significant progress has been achieved with the development and use of tools and methods of sustainable design. Also, biomimetics has been researched and used as an approach to sustainable design. From the perspective of engineering design, design against crime may benefit through the use of biological design principles in order to address crime issues. Thus, in dealing with crime issues, how would these principles assist designers to approach crime when designing and developing new products? This paper recounts an ongoing research project that has identified some biological design properties or principles of living systems that can be extrapolated, synthesised and integrated into new products or systems. It seems that these properties have enabled biological organisms to survive in rough environments and evolve through time. It is hoped that designers, when approaching crime in the design process of new products or systems, can use these principles.
\end{abstract}

Keywords: biological principles, design, crime, biomimetics.

\section{Introduction}

There has been an underlying expression of opinion within the academic and law enforcement community that the nature of crime and criminals has changed. Crime has become global, but with significant national, regional and local 
impact. This includes cyber-crime, drug trafficking, human trafficking, other forms of trafficking and smuggling, money laundering, and terrorism. On the other hand, law enforcement institutions have evolved significantly in their methods and tools of dealing with crime over the last few years [1,2]. These new tools, methods and thinking constitute what is known as crime science. In essence, crime science, very much like operations research, employs scientific know-how in order to prevent and control crime [2]. Crime science embraces, amongst others, disciplines, such as engineering design, statistics, biochemistry, material science, criminology, psychology, sociology, communications, artificial intelligence, zoology, and ecology. In the continued pursuit of improved product quality, reduced cost and time to market, there has been a necessity to design products that satisfy both customers and the environment [3]. More recently, engineering design principles have been used to approach crime in the design process $[2,4]$. Similarly, in recent years it seems that engineers have an increased interest in borrowing design concepts from nature [5,6]. The discipline of biomimetics has grown to the point that books, articles, conference sessions, and university programs are now commonplace. From the engineering design perspective, it is clear that design against crime can benefit from biological design principles. Thus, in dealing with crime issues, how would these principles assist designers to approach crime when designing and developing new products? This paper recounts an ongoing research project that has identified biological design properties of living systems that can be extrapolated, synthesised and integrated into new products or systems. In the remaining sections of the paper, the literature review, preliminary results, and conclusions and further research are presented.

\section{Design, crime and biomimetics}

\subsection{Engineering design}

Engineers use design processes, tools and methods for solving problems, meeting needs, improving situations, or creating something new. Decisionmaking philosophies in the design process have changed drastically over the last decade from sequential engineering to concurrent engineering (CE) [7]. CE seeks the simultaneous progress of activities required to introduce products to the market place at the right time, cost and quality. In a $\mathrm{CE}$ environment, designers make decisions about many product attributes, such as function, structure, shape, strength, material, cost, regulations, and other requirements in a concurrent way [8]. One of the most powerful CE tools for translating customer requirements into technical systems requirements is the quality function deployment (QFD) matrices. It is argued elsewhere $[9,10]$ that the QFD matrices provide a systematic process for identifying the critical customer attributes and to create a specific link between the voice of the customer and the new product parameters, which then are translated into production requirements. Another widely used tool is the Pugh concept selection for evaluating and selecting new concepts [11]. Pugh argues that the concept selection method aims at selecting the least 
vulnerable concept, which initiates the final detailed design process. Other common tools and methods, such as multi-criteria decision-making, are used to assist designers in making decisions in the concept development process [12]. Optimisation tools and methods, such as the multi-attribute design optimisation, non-linear programming, and robust design have been used extensively by designers. Engineering design has been a vital activity in order to address the lifecycle environmental impact of products or systems $[3,13]$, and to approach crime issues $[2,4]$ over the last few years.

\subsection{Crime science}

Until very recently, approaches to crime, including the decision-making process, have been enhanced by methods and tools of science. That is, law enforcement, judicial, legislative and related institutions are working hard using scientific tools in order to approach crime. A whole cluster of concepts, methods and tools has been emerging over the last decade. These new tools, methods and thinking constitute what is known as crime science. In general, crime science, very much like operational research, employs scientific know-how in order to approach crime issues [2]. Crime science embraces, amongst others, disciplines, such as engineering design, biochemistry, material science, statistics and probability theory, criminology, psychology, sociology, communications, artificial intelligence, zoology, and ecology. Crime science is emerging as an exciting field of research and innovation. The discipline has developed a core research agenda, an increasing flow of results that effect significant changes in the practice of crime control, and a growing number of institutions committed to teaching its methods and findings [14,15]. Just like engineering science and health science, it seems that crime science is defined by the problems it addresses rather than by the concerns of the disciplines it employs. In particular, the field focuses on understanding the complex dynamics that arise from the interactions between social, economical and technological, and environmental systems. Its ultimate goal is to facilitate a transition towards a society free of crime.

\subsection{Biomimetics}

It is well known that early engineering systems were developed through inspiration from nature [5]. Over the last few years, there seems to be growing interest on the part of designers to borrow design concepts from biological systems. This process is commonly known as biomimetics. It offers an interesting approach to design in an environment of sustainable and creative design (16). Biomimetics is a multi-disciplinary subject involving a wide diversity of disciplines like electronics, informatics, medicine, biology, chemistry, physics, mathematics, art and many other engineering disciplines $(6,17)$. In more advanced applications, researchers use model systems to try to understand the complex structure and self-organisation of cells, for example. Moreover, the overwhelming advances in biology, practiced at higher levels of biological complexity, such as animals, provide opportunities for benefiting from 
biomimetics. Animal biologists now understand how basilisk lizards walk on water [18], how penguins minimise drag [19], and how insects manage to remain airborne [20,21]. This knowledge identifies specific relationships between functions and structures that can provide assistance to designers when faced with analogous problems. Thus, in dealing with crime issues, how would this understanding assist designers to approach crime when designing and developing new products?

\section{Biological insight into design against crime}

In order to identify biological models or principles that may be used to approach crime in the design process of products, a four step methodology is used. First, an insight is developed from the similitude between crime and biological situations. Second, an analogy is drawn from the biological situation to the crime situation. Third, a more rigorous formulation is attempted. Finally, generalised scientific models or inherent principles are established.

\subsection{An insight from crime and biological situation}

In this first step, the aim is to comprehend the simile between crime and biological situations. Over the last few years, a great deal of research has been realised in order to understand the nature of crime, and to approach it from different perspectives. Regardless of the perspective of the approach, they all deal with victims' and offenders' issues. Similarly, biologists have long researched and understood the behaviour of biological systems. In particular, they have developed a thorough understanding of the interaction of prey and predator organisms. This understanding might be useful to approach crime when designing products.

\subsection{An analogy between crime and biological situations}

The aim of this step is to explore the analogy between the behaviour of victimoffender interactions and prey-predator interactions. The nature of crime may be characterised by events involving behaviour deemed against law, but above all against human safety, health and security. These events range from murder to fraud, theft, vandalism, sexual and rape, dealing with drugs, kidnappings, and terrorists acts that threaten public safety. These events threaten the capacity of human beings to survive. Survival has a biological connotation. In the biological kingdom, for most organisms escaping predation is essential to their survival. They have developed a great diversity of survival strategies, such as warning signals, unpalatable traits, shield protection, and noxious features, in order to avoid predators. Organisms or animals have evolved to advertise their unprofitability to predators [22-24]. Prey gain their greatest selective advantage when predators have already experienced similar signals [22]. Many researchers have investigated the benefits of mimics, which promotes deception if the organisms are palatable or through spreading the cost of educating predators if they are also noxious [25]. Some species use shields, which vary in appearance 
and physical consistency, in order to deter a number of predators [26]. Other organisms employ complex noxious substances or venom as a predator deterrent strategy [27]. Many investigations have been realised in order to understand the strength of interactions among species within natural communities [28]. Other organisms, such as herbivores reduce their vulnerability to natural enemies through adaptation to host plants [29].

\subsection{Rigorous formulation}

The purpose of this step is to formulate design principles that can be formally expressed and tested. However, this process has already been carried out by the biological systems researcher, thus one can look up the results. These results, such as those reported by researchers mentioned in the previous step, are scientific models that can be mapped into crime situations when designing new products or systems. The mapping has been done by using the idea of isomorphism. Isomorphic mappings means, roughly, similar in pattern. Prey and predator interactions and victim and offender interactions are, so far as the pattern of survival is concerned, isomorphic. The use of isomorphic systems is thus important, because crime situations have both difficult and easy issues in their properties. Designers might come to a difficult issue in the particular crime situation he/she is addressing in a new design. He/she may, if an isomorphic form exists, finds that the corresponding property in the other form is much easier to understand, control, or investigate. In this way, survival models proposed by biologists are being taken as being isomorphic with survival issues of humans regarding crime.

\subsection{Generalisation: inherent design against crime principles}

In this last step, scientific principles are now available, consisting of patterns of behaviour of prey and predators. Several principles have been identified, which have an identity relationship, survival, between humans and animals over a precisely defined area of concern and not over others. Table 1 lists some of the biological issues investigated and formally tested by biologists. These issues are biological models, called here as inherent principles, for designing against crime. It is possible that some adjustments may need to be made in order to integrate them into new concepts of products or systems.

These principles may be said to be inherently design against crime principles if designers consider crime issues at the conceptual stage of product design. Ultimately, the aim is to attain no crime situations. However, there is always the possibility of crimes. Clearly, these principles need to be adapted and applied to practical design cases in order to verify their practical usefulness.

\section{Conclusions and future work}

This paper has proposed a set of principles, called inherently design against crime principles, in order to address crime issues at an early product design stage. A systematic process has been used in order to identify these principles 
Table 1: Biological design principles.

\begin{tabular}{|c|c|c|}
\hline Principle & Description & Implications for design \\
\hline Aposematism & $\begin{array}{l}\text { Aposematism possesses an } \\
\text { obvious advantage as a } \\
\text { defensive strategy against } \\
\text { educated predators; i.e., some } \\
\text { prey species are unprofitable as } \\
\text { food, and other organisms are } \\
\text { even fatally toxic. Thus, it is an } \\
\text { advantage for the predators to } \\
\text { avoid such prey [22-24]. }\end{array}$ & $\begin{array}{l}\text { It can be integrated as an inherent } \\
\text { feature of a new product or system, } \\
\text { where products or systems signal } \\
\text { conspicuously to offenders the cost } \\
\text { of making an attack. }\end{array}$ \\
\hline Coevolution & $\begin{array}{l}\text { "The particular physical and } \\
\text { physiological characteristics of } \\
\text { the host plant are thought to be } \\
\text { major features influencing the } \\
\text { vulnerability of insect } \\
\text { herbivores to attack by } \\
\text { predators and parasitoids, and } \\
\text { adaptation to those specific } \\
\text { characteristics may be expected } \\
\text { to play an important role in } \\
\text { avoiding attack by natural } \\
\text { enemies" [28]. }\end{array}$ & $\begin{array}{l}\text { Products or systems might reduce } \\
\text { their vulnerability to criminals } \\
\text { through adaptation to customers, } \\
\text { users or operators. }\end{array}$ \\
\hline Mimicry & $\begin{array}{l}\text { Mimicry means groups of } \\
\text { species that are connected by } \\
\text { analogous resemblances. For } \\
\text { example, non-poisonous species } \\
\text { adaptively resemble unpalatable } \\
\text { species, or models. If sampled } \\
\text { by a predator, the palatable } \\
\text { mimics will discourage future } \\
\text { attacks, and may enhance } \\
\text { attacks on the model [25]. }\end{array}$ & $\begin{array}{l}\text { Products or systems may benefit } \\
\text { through deception or spreading the } \\
\text { cost of educating offenders if the } \\
\text { product or system is also noxious. }\end{array}$ \\
\hline Shield protection & $\begin{array}{l}\text { Shields of various appearance } \\
\text { and physical consistency are } \\
\text { used to deter a number of } \\
\text { enemies [26]. }\end{array}$ & $\begin{array}{l}\text { This feature can be integrated into } \\
\text { products or systems as means of } \\
\text { protection. }\end{array}$ \\
\hline
\end{tabular}

from published scientific knowledge regarding behaviour of biological systems. It is hoped that these principles may provide an insight into how to prevent crime issues from the beginning of a product or system lifecycle. As future work, these principles need to be applied, as case studies or real design projects, in order to verify their practical usefulness.

\section{References}

[1] Dorriety, J.K., Police Service Dogs in the Use-of-Force Continuum, Criminal Justice Policy Review, Volume 16, Number 1, March 2005, pp. 88-98.

[2] Smith, M.J. \& Tilley, N., (eds.). Crime Science: New approaches to preventing and detecting crime. Willan Publishing, 2005. 
[3] Santos-Reyes, D.E., \& Lawlor-Wright, T., A design for the environment methodology to support environmental management systems, Integrated Manufacturing Systems, 12/5, 2001, pp. 323-332.

[4] Santos-Reyes, D., \& Santos-Reyes, J., Patterns and rates of crime evolution in Mexico, WIT Transactions on the Built Environment, 2007, pp. 119-127.

[5] Vogel, S., Cats' Paws and Catapults: Mechanical Worlds of Nature and People, Norton, New York, 1998.

[6] Benyus, J.M., Biomimicry innovation inspired by nature, Harper-Collins Publishers, New York, 1997.

[7] Prasad, B., Concurrent Engineering Fundamentals: Integrated Product and Processes Organization, Vol. 1, Upper Saddle River, NJ: Prentice-Hall Inc., 1996.

[8] Nahm, E.Y., \& Ishikawa, H., Integrated product and process modelling for collaborative design environment, Concurrent engineering: research and applications, 2004, Vol. 12, Number 1, March 2004, pp. 5-23.

[9] Hauser, J.R., \& Clausing, D., The House of Quality, Harvard Business Review, 1988, May-June, pp. 63-73.

[10] Akao, Y., Quality function deployment-integrating customer requirements into product design, Cambridge, MA: Productivity Press Inc., 1990.

[11] Pugh, S., Total design: integrated methods for successful product engineering, Addison-Wesley Publishing Company, 1995.

[12] Yeo, S.H., Mak, M.W. \& Balon, S.A.P., Analysis of decision-making methodologies for desirability score of conceptual design, J. Eng. Design, Vol. 15, No. 2, April 2004, pp. 195-208.

[13] Alting, L., Designing for a life time, Manufacturing Breakthrough, 1993, May/June, pp. 29-33.

[14] Corley, C.J., Nalla, M.K., \& Hoffman, V.J., Components of an Appropriate Graduate-level Corrections Curriculum, Criminal Justice Studies, Vol. 18, No. 4, December 2005, pp. 379-392.

[15] Finckenauer, J.O., The Quest for Quality in Criminal Justice Education, Justice Quarterly, Volume 22, Number 4, December 2005, pp. 413-426.

[16] http://people.bath.ac.uk/en2ral/biomimeticprocess.html, April, 2007.

[17] M. Sarikaya, Biomimetics: Materials Fabrication through Biology, PNAS, 96 (25), 1999, pp. 14183-86.

[18] Glasheen, J. W. \& McMahon, T. A., A hydrodynamic model of locomotion in the Basilisk Lizard, Nature, 380, (28 March 1996), pp. 340-342.

[19] Culik, B. M., Wilson, R. P., \& Bannasch, R., Underwater swimming at low energetic cost by pygoscelid penguins, J. Exp. Biol., 197, (1994), pp. 6578.

[20] Dickinson, M. H., Lehmann, F-O., \& Sane, S. P., Wing Rotation and the aerodynamic basis of insect flight, Science, 18, June 1999, pp. 1954-1960.

[21] Ellington, Ch. P., van den Berg, C., Willmott, A. P. \& Thomas, A. L. R., Leading-edge vortices in insect flight, Nature, 384, (26 December 1996), pp. 626-630.

[22] Brodie III, E. D. \& Agrawal, A. F. Maternal effects and the evolution of aposematic signals, PNAS, July 3, 2001, vol. 98, no. 14, pp. 7884-7887. 
[23] Edmunds, M., Defence in Animals: A Survey of Anti-Predator Defences (Longman, London), 1974.

[24] Ruxton, G. D., Sherratt, T. N. \& Speed, M. P., Avoiding Attack: The Evolutionary Ecology of Crypsis, Aposematism, and Mimicry, (Oxford Univ. Press, Oxford, U.K.), 2004.

[25] Barber, J. R. and Conner, W. E., Acoustic mimicry in a predator-prey interaction, $P N A S$, May 29, 2007, vol. 104, no. 22, pp. 9331-9334.

[26] Eisner, T. and Eisner, M., Defensive use of a fecal thatch by a beetle larva (Hemisphaerota cyanea), PNAS, March 14, 2000, vol. 97, no. 6, pp. 26322636.

[27] Inceoglu, B., Lango, J., Jing, J., Chen, L., Doymaz, F., Pessah, I. N. \& Hammock, D. B., One scorpion, two venoms: Prevenom of Parabuthus transvaalicus acts as an alternative type of venom with distinct mechanism of action, PNAS, February 4, 2003, vol. 100, no. 3, pp. 922-927.

[28] Sala, E. \& Graham, M. H., Community-wide distribution of predator-prey interaction strength in kelp forests, PNAS, March 19, 2002, vol. 99, no. 6, 3678-3683.

[29] De Moraes, C. M. \& Mescher, M. C., Biochemical crypsis in the avoidance of natural enemies by an insect herbivore, PNAS, June 15, 2004, vol. 101, no. 24, 8993-8997. 